T. Tomita $\cdot$ H. Masuzaki $\cdot$ H. Iwakura $\cdot$ J. Fujikura $\cdot$ M. Noguchi $\cdot$ T. Tanaka

K. Ebihara · J. Kawamura $\cdot$ I. Komoto $\cdot$ Y. Kawaguchi $\cdot$ K. Fujimoto $\cdot$

R. Doi $\cdot$ Y. Shimada $\cdot$ K. Hosoda $\cdot$ M. Imamura $\cdot$ K. Nakao

\title{
Expression of the gene for a membrane-bound fatty acid receptor in the pancreas and islet cell tumours in humans: evidence for GPR40 expression in pancreatic beta cells and implications for insulin secretion
}

Received: 3 August 2005 / Accepted: 23 December 2005 / Published online: 9 March 2006

C) Springer-Verlag 2006

\begin{abstract}
Aims/hypothesis G protein-coupled receptor 40 (GPR40) is abundantly expressed in pancreatic beta cells in rodents, where it facilitates glucose-induced insulin secretion in response to mid- to long-chain fatty acids in vitro. However, GPR40 gene expression in humans has not been fully investigated, and little is known about the physiological and pathophysiological roles of GPR40 in humans. The aim of this study, therefore, was to examine GPR40 expression and its clinical implications in humans. Methods: GPR40 mRNA expression in the human pancreas, pancreatic islets and islet cell tumours was analysed using TaqMan PCR. Results: GPR40 mRNA was detected in all human pancreases collected intraoperatively. It was enriched approximately 20 -fold in isolated islets freshly prepared from the pancreases of the same individuals. The estimated mRNA copy number for the GPR40 gene in pancreatic islets was comparable to those for genes encoding sulfonylurea receptor 1 , glucagon-like peptide 1 receptor and somatostatin receptors, all of which are known to be expressed abundantly in the human pancreatic islet. A large amount of GPR 40 mRNA was detected in insulinoma tissues, whereas mRNA expression was undetectable in glucagonoma or gastrinoma. The GPR 40 mRNA level in the pancreas correlated with the insulinogenic index, which reflects beta cell function $(r=0.82, p=0.044)$, but not
\end{abstract}

T. Tomita $\cdot$ H. Masuzaki $(\bowtie) \cdot$ H. Iwakura $\cdot$ J. Fujikura M. Noguchi - T. Tanaka - K. Ebihara - K. Hosoda - K. Nakao Department of Medicine and Clinical Science, Kyoto University Graduate School of Medicine, 54 Shogoin Kawahara-cho, Sakyo-ku, Kyoto 606-8507, Japan

e-mail: hiroaki@kuhp.kyoto-u.ac.jp

Tel.: +81-75-751-3172

Fax: $+81-75-771-9452$

J. Kawamura · I. Komoto · Y. Kawaguchi · K. Fujimoto ·

R. Doi · Y. Shimada · M. Imamura

Department of Surgery and Surgical Basic Science, Kyoto University Graduate School of Medicine, Kyoto, Japan with glucose levels during the OGTT, the insulin area under the OGTT curve or the index for the homeostasis model assessment of insulin resistance (HOMA-IR). Conclusions/interpretation The present study provides evidence for GPR40 gene expression in pancreatic beta cells and implicates GPR40 in insulin secretion in humans.

Keywords Human · GPR40 - Pancreas · Pancreatic islets · Insulinoma $\cdot$ Insulin secretion

Abbreviations GLP1R: glucagon-like peptide 1 receptor GPR40: G protein-coupled receptor 40 - GSIS: glucosestimulated insulin secretion - HOMA-IR: homeostasis model assessment of insulin resistance - SSTR: somatostatin receptor - SUR1: sulfonylurea receptor 1

\section{Introduction}

Fatty acids play a pivotal role in a variety of metabolic controls and cell signalling processes in various tissues [1]. In particular, short-term exposure of fatty acids to pancreatic beta cells augments glucose-stimulated insulin secretion (GSIS), a process in which fatty acid-derived metabolites such as long-chain fatty acyl-CoAs act as crucial effectors [2]. However, the entire mechanism whereby fatty acids acutely induce GSIS augmentation has not been fully elucidated [3]. In contrast, chronic fatty acid exposure causes marked deterioration of beta cell function, which is referred to as lipotoxicity $[4,5]$.

Several investigators have recently demonstrated that fatty acids act as ligands for membrane-bound G-proteincoupled receptors such as GPR40 [3, 6, 7], GPR41, GPR43 $[8,9]$ and GPR 120 [10]. GPR40 is preferentially expressed in pancreatic beta cells in rodents and augments GSIS after acute exposure to mid- and long-chain fatty acids [6]. Silencing GPR40 with the small interfering RNA (siRNA) system suppresses long-chain fatty acid-induced GSIS augmentation in pancreatic beta cells [6]. A recent study of 
GPR40 knockout mice and beta-cell-specific GPR40 transgenic mice suggested a physiological and pathophysiological role for GPR40 in insulin secretion and diabetes mellitus [11]. Although these findings implicate GPR40 in insulin secretion and glucose metabolism in rodents, little is known about the physiological significance of GPR40 in humans.

In this context, we investigated GPR40 gene expression in the pancreas and in islet cell tumours collected during surgery. We also explored the potential role of GPR40 in beta cell function in humans.

\section{Subjects and methods}

Participants, tissue sampling and pancreatic islet preparation

Seventeen patients with pancreatic tumours provided written informed consent to participation in the present study, which was approved by the Ethical Committee on Human Research of Kyoto University Graduate School of Medicine (No. 508, 2003), and conducted according to the principles of the Declaration of Helsinki. Table 1 summarises the patient profiles. Patients who underwent pancreatectomy (patients 1-12) were numbered according to the GPR40 mRNA level in the pancreas. None of the 12 patients were treated with oral glucose-lowering agents or insulin. Pancreatic, intestinal and hepatic tissues free of tumour invasion as well as islet cell tumour tissues were obtained at the time of surgery (Table 1). Islet tissues from three patients (patients 9-11) were promptly isolated from the pancreas through the mince method [12]. Briefly, the pancreas was finely minced by hand for $15-30 \mathrm{~min}$ on ice and digested at $37^{\circ} \mathrm{C}$ with $600 \mathrm{IU} / \mathrm{ml}$ of type $\mathrm{V}$ collagenase (Sigma, St Louis, MO, USA) in Hanks' Balanced Salt Solution (HBSS) containing 1\% bovine serum albumin (Fraction V, Sigma) for $20 \mathrm{~min}$. The digested tissue was washed three times in cold HBSS. After dithizone staining, pancreatic islets were manually collected using a stereo microscope (SZ-STB1; Olympus, Tokyo, Japan).

Quantification of mRNA expression of GPR40 and other receptor genes

We measured mRNA expression of the GPR 40 gene as well as genes encoding sulfonylurea receptor 1 ( $A B C C 8$, previously known as SUR1) [13], glucagon-like peptide 1 receptor $(G L P 1 R)[14,15]$ and somatostatin receptor (SSTR) 3 and 5 [16] using the following method. Total RNA was extracted using the Qiagen RNeasy Mini Kit (Qiagen, Hilden, Germany) [17]. First-strand cDNA was synthesised by random hexamer-primed reverse transcription using SuperScript II reverse transcriptase (Invitrogen, Carlsbad, CA, USA) [18]. The mRNA level was quantified by the TaqMan PCR method using an ABI Prism 7700 Sequence Detector (Applied Biosystems, Foster City, CA, USA) as described [19]. To calculate the copy number of each mRNA, standard curves were generated using synthesised oligo DNA fragments (Proligo Japan, Kyoto, Japan) containing the PCR amplicon region. The mRNA expression in each gene was normalised to that of GAPDH (i.e. the mRNA level for each gene was expressed as

Table 1 Clinical profiles of patients and tissues

\begin{tabular}{lllll}
\hline Patient number & Age (years) & Sex $(\mathrm{M} / \mathrm{F})$ & Disease & Tissue analysed \\
\hline 1 & 53 & $\mathrm{~F}$ & Pancreatic cancer & Pancreas (head)/duodenum \\
2 & 47 & $\mathrm{~F}$ & Pancreatic cancer & Pancreas (head)/jejunum \\
3 & 71 & $\mathrm{~F}$ & Pancreatic cancer & Pancreas (body) \\
4 & 59 & $\mathrm{~F}$ & Insulinoma & Pancreas (head)/insulinoma \\
5 & 72 & $\mathrm{~F}$ & Pancreatic cancer & Pancreas (head)/jejunum \\
6 & 75 & $\mathrm{M}$ & Pancreatic cancer & Pancreas (head)/duodenum/jejunum \\
7 & 45 & $\mathrm{M}$ & Gastrinoma & Pancreas (body) \\
8 & 63 & $\mathrm{~F}$ & Islet cell tumour (non-functional) & Pancreas (body) \\
9 & 60 & $\mathrm{M}$ & Pancreatic cancer & Pancreas (body) \\
10 & 63 & $\mathrm{M}$ & Pancreatic cancer & Pancreas (head) \\
11 & 54 & $\mathrm{M}$ & Pancreatic cancer & Pancreas (head) \\
12 & 55 & $\mathrm{~F}$ & Pancreatic cancer & Pancreas (body) \\
13 & 64 & $\mathrm{~F}$ & Liver metastasis (glucagonoma) & Liver \\
14 & 54 & $\mathrm{~F}$ & Insulinoma & Insulinoma \\
15 & 30 & $\mathrm{M}$ & Insulinoma & Insulinoma \\
16 & 23 & $\mathrm{~F}$ & Glucagonoma & Glucagonoma \\
17 & 56 & $\mathrm{M}$ & Gastrinoma & Gastrinoma \\
\hline
\end{tabular}

Patients were premedicated with $0.01 \mathrm{mg} / \mathrm{kg}$ atropine sulphate i.m. and $0.2 \mathrm{mg} / \mathrm{kg}$ diazepam orally before surgery Tissues were sampled under general anaesthesia with $35 \% \mathrm{O}_{2}, 65 \% \mathrm{~N}_{2} \mathrm{O}$ and $0.5-1.5 \%$ sevoflurane. Neuromuscular blockade was provided with vecuronium bromide; initial dose $0.1 \mathrm{mg} / \mathrm{kg}$, supplemented as required 
receptor/GAPDH [copy/copy]). Table 2 summarises the sequences of primers and probes used in the present study. The primers or probes were designed not to cover any reported single-nucleotide polymorphisms [20-23].

Data analysis on glucose homeostasis

The insulin AUC was calculated using the trapezoidal rule from OGTT data. We evaluated beta cell function and systemic insulin resistance using the insulinogenic index $(n=7)$ and the homeostasis model assessment of insulin resistance (HOMA-IR) $(n=10)$, respectively. The insulinogenic index was calculated as the ratio of the insulin concentration (pmol/l) increment to the glucose concentration $(\mathrm{mmol} / \mathrm{l})$ increment at $30 \mathrm{~min}$ into the OGTT $(\Delta 30$ insulin/ $\Delta 30$ glucose $)[24]$. HOMA-IR was calculated in fasting conditions as plasma insulin $(\mathrm{pmol} / \mathrm{l}) \times$ blood glucose $(\mathrm{mmol} / \mathrm{l}) / 22.5[25,26]$. The difference in the patient numbers for the two indices is based on the difference in data availability, such as blood glucose and insulin levels at $30 \mathrm{~min}$ during the OGTT.

\section{Statistical analysis}

The relationship between the GPR40 mRNA level in the pancreas and clinical or metabolic profiles was tested using Spearman's rank correlation and a $p$ value of less than 0.05 was considered significant. The statistical significance of differences in two groups was assessed using unpaired twotailed $t$-test and a $p$ value of less than 0.05 was considered significant (Statcel, Social Research Information, Tokyo, Japan).

\section{Results}

Expression of GPR40 mRNA in human pancreas and isolated islets

The expression of GPR40 mRNA in human tissues was assessed by TaqMan PCR using total RNA samples from patients who underwent pancreatectomy and/or other pertinent surgeries. GPR 40 mRNA was detected in all human pancreases examined $(n=12)$, and at higher levels than those in the duodenum, jejunum or liver (Fig. 1a). The inter-individual variability in the GPR 40 mRNA levels was considerable in the human pancreas. The GPR40 mRNA level in the pancreas was not significantly different between sites (head vs body) of the pancreas or between men and women. The GPR 40 mRNA level in the pancreas did not correlate significantly with age. The GPR 40 mRNA level in fresh islets that were isolated from pancreatic tissues $(n=3)$ was approximately 20 -fold higher than that in the pancreas from the same patients (Fig. 1b).

To gain further insight into the expression of the GPR40 gene in pancreatic islets, we analysed the expression of genes known to be expressed abundantly in the pancreatic islets. The estimated mRNA copy number of the GPR40 gene in isolated islets was comparable to or higher than those of genes encoding receptors for sulfonylurea, glucagon-like peptide 1 and somatostatin (Fig. 1c), suggesting that high levels of the GPR 40 gene are expressed in pancreatic islets.

Expression of GPR40 mRNA in insulinoma tissues

We analysed the expression of GPR40 mRNA in islet cell tumours, including insulinoma $(n=3)$, glucagonoma $(n=1)$

Table 2 Sequences of TaqMan primers and probes

\begin{tabular}{|c|c|c|c|c|}
\hline Gene & Forward primer $\left(5^{\prime} \rightarrow 3^{\prime}\right)$ & Probe $\left(\right.$ FAM-5' $\rightarrow 3^{\prime}$-TAMRA) & $\begin{array}{l}\text { Reverse Primer } \\
\left(5^{\prime} \rightarrow 3^{\prime}\right)\end{array}$ & $\begin{array}{l}\text { Accession } \\
\text { number }\end{array}$ \\
\hline GPR40 & $\begin{array}{l}\text { GCCCGCTTCAGCC } \\
\text { TCTCT }\end{array}$ & $\begin{array}{l}\text { TCTGCCCTTGGCCATCA } \\
\text { CAGCCT }\end{array}$ & $\begin{array}{l}\text { GAGGCAGCCCAC } \\
\text { GTAGCA }\end{array}$ & NM_005303 \\
\hline$G L P 1 R$ & $\begin{array}{l}\text { GCAGCCCTGAAGTGG } \\
\text { ATGTATAG }\end{array}$ & $\begin{array}{l}\text { ACAGCCGCCCAGCAGCA } \\
\text { CCAGT }\end{array}$ & $\begin{array}{l}\text { CTCAGAGAGTCCT } \\
\text { GGTAGGAGAG }\end{array}$ & NM_002062 \\
\hline$A B C C 8$ & $\begin{array}{l}\text { GCTGCCCATCGTTATG } \\
\text { AGGG }\end{array}$ & $\begin{array}{l}\text { CCTCACCAACTACCAACG } \\
\text { GCTCTGCG }\end{array}$ & $\begin{array}{l}\text { GAATGTCCTTCCG } \\
\text { CACCTGG }\end{array}$ & NM_000352 \\
\hline SSTR3 & $\begin{array}{l}\text { CCGTCAGTGGCGTTCT } \\
\text { GATCC }\end{array}$ & $\begin{array}{l}\text { CCACCACGCACACCACC } \\
\text { AGGTAGACC }\end{array}$ & $\begin{array}{l}\text { ATAGATGACCAGC } \\
\text { GAGTTACCCAG }\end{array}$ & NM_001051 \\
\hline SSTR5 & $\begin{array}{l}\text { CTCGGAGCGGAAGGT } \\
\text { GACG }\end{array}$ & $\begin{array}{l}\text { AACACCAGCACCACCACCAA } \\
\text { CACCAT }\end{array}$ & $\begin{array}{l}\text { GTGAAGAAGGGCA } \\
\text { GCCAACATC }\end{array}$ & NM_001053 \\
\hline$G A P D H$ & $\begin{array}{l}\text { TGAAGCAGGCGTCGG } \\
\text { AGG }\end{array}$ & $\begin{array}{l}\text { CCTCAAGGGCATCCTGGGCTA } \\
\text { CACTG }\end{array}$ & $\begin{array}{l}\text { GCTGTTGAAGTCAG } \\
\text { AGGAGACC }\end{array}$ & NM_002046 \\
\hline
\end{tabular}

The $A B C C 8$ gene is also known as $S U R 1$ and encodes sulfonylurea receptor 1

FAM 6-carboxyfluorescein, TAMRA 6-carboxytetramethylrhodamine 
Fig. 1 TaqMan quantitative analyses of GPR40 mRNA expression in human pancreatic tissues. Total RNA extracted from various tissues was analysed. a GPR40 mRNA was detected in all human pancreas specimens examined, at higher abundance than in the duodenum, jejunum or liver. Patients 1-12 were numbered according to their relative level of expression of GPR40 mRNA. b GPR40 mRNA level in isolated islets was $\sim 20$-fold higher than in pancreatic tissues from the same patients. The numbers in $\mathbf{a}$ and $\mathbf{b}$ correspond to those in Table 1. c Estimated mRNA copy number of the GPR40 gene was similar to or higher than those for genes encoding sulfonylurea receptor 1

$(A B C C 8)$, glucagon-like peptide 1 receptor $(G L P 1 R)$ and somatostatin receptors 3 (SSTR3) and $5(\operatorname{SSTR} 5)(n=3)$. Data are means \pm SEM. Open bars pancreas; closed bars isolated islets a

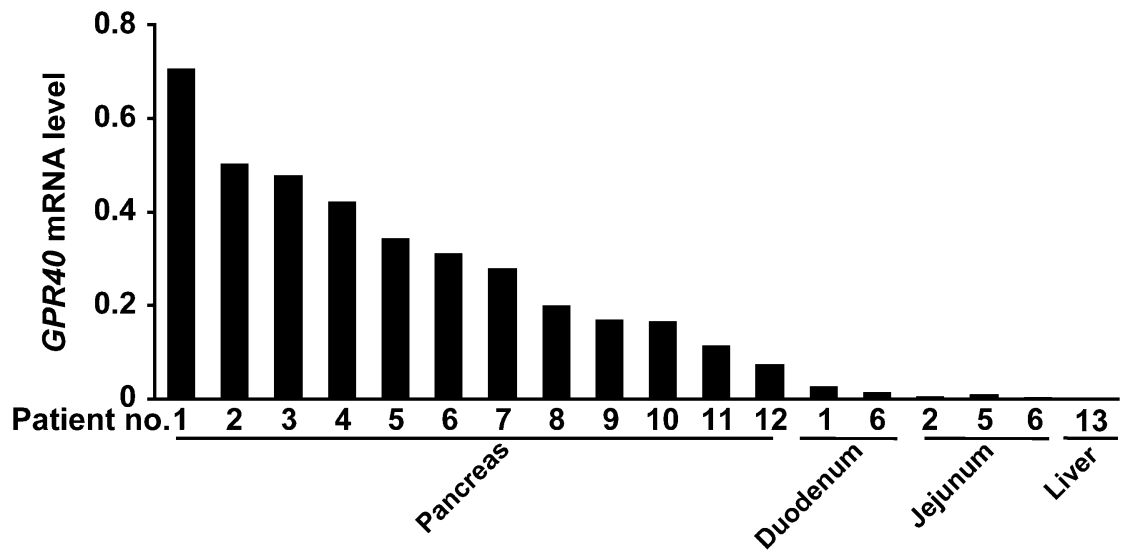

b

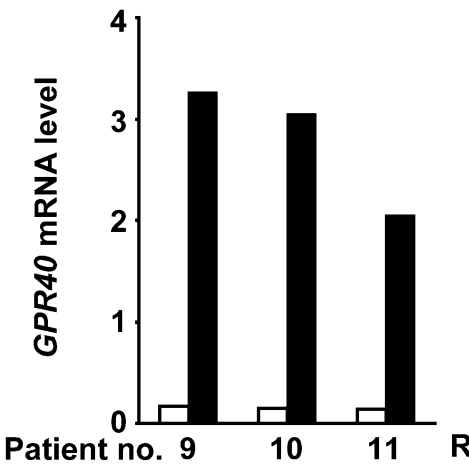

C

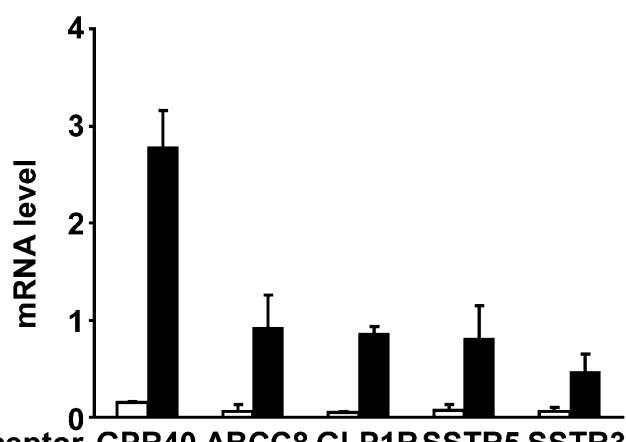

and gastrinoma $(n=1)$. GPR40 mRNA was detected in tissue extracts from three cases of insulinoma (Fig. 2), which was comparable to that in pancreatic islets (Fig. 2). GPR40 mRNA was below detectable levels in tissue extracts from glucagonoma or gastrinoma (Fig. 2).

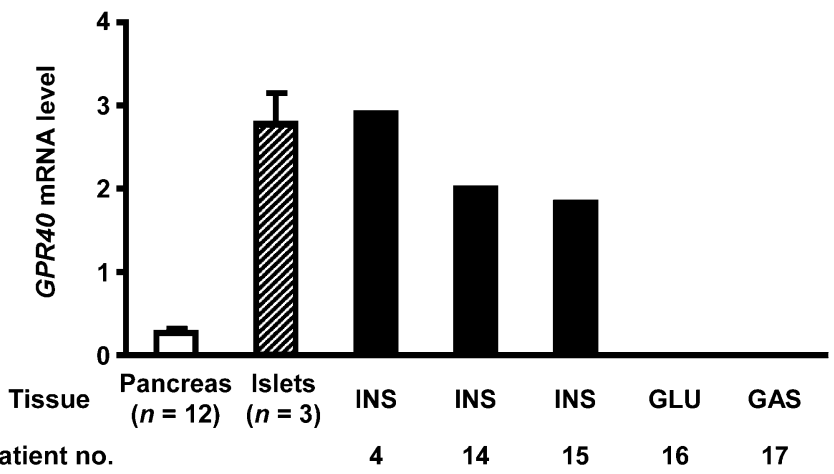

Fig. 2 TaqMan quantitative analyses of GPR40 mRNA expression in human islet cell tumours. Total RNA extracted from pancreases $(n=12)$, pancreatic islets $(n=3)$ and islet cell tumours (patients 4,14 , $15,16,17)$ was analysed. GPR 40 mRNA was abundantly expressed in three cases of insulinoma among islet cell tumours. Open bar, pancreas; hatched bar, pancreatic islets; closed bars, islet cell tumours. The patient numbers in the figure correspond to those in Table 1. The GPR40 mRNA level in the pancreas and pancreatic islets is expressed as mean \pm SEM. INS insulinoma, GLU glucagonoma, GAS gastrinoma
The correlation between the GPR40 mRNA level in the pancreas and insulinogenic index is positive

To understand the physiological role of GPR40 in humans, we examined the relationship between the GPR 40 mRNA level in the pancreas and various metabolic parameters. Table 3 summarises the metabolic profiles of patients who underwent pancreatectomy. The GPR 40 mRNA level in the pancreas did not correlate significantly with BMI, fasting plasma glucose, plasma glucose at $2 \mathrm{~h}$ under the OGTT (2h-PG) or insulin AUC. Furthermore, the GPR40 mRNA level in the pancreas did not correlate significantly with the HOMA-IR $(n=10)$ (Fig. 3a). The significant positive correlation between the GPR 40 mRNA level in the pancreas and the insulinogenic index was notable $(n=7)$ ( $p=0.044, r=0.82$ ) (Fig. 3b). To verify the significant association, correlation was tested between the GPR40 mRNA level in the pancreas and the HOMA-IR, using data from the same patients from whom data on the insulinogenic index were available $(n=7)$, and we confirmed that there was no significant correlation between the GPR40 mRNA level and the HOMA-IR $(p=0.86, r=0.07)$. The GPR40 mRNA level in the pancreas was not significantly associated with $\mathrm{HbA}_{1 \mathrm{c}}$ or fasting triglyceride. 
Table 3 Metabolic profiles of patients studied

\begin{tabular}{lllllllll}
\hline Patient & $\begin{array}{l}\text { BMI } \\
\left(\mathrm{kg} / \mathrm{m}^{2}\right)\end{array}$ & $\begin{array}{l}\text { FPG } \\
(\mathrm{mmol} / \mathrm{l})\end{array}$ & $\begin{array}{l}2 \mathrm{~h}-\mathrm{PG} \\
(\mathrm{mmol} / \mathrm{l})\end{array}$ & $\begin{array}{l}\text { Insulin AUC } \\
\left(\times 10^{3} \mathrm{pmol} / \mathrm{l}\right)\end{array}$ & HOMA-IR & $\begin{array}{l}\text { Insulinogenic } \\
\text { index }\end{array}$ & $\begin{array}{l}\mathrm{HbA}_{1 \mathrm{c}} \\
(\%)\end{array}$ & $\begin{array}{l}\text { Triglycerides } \\
(\mathrm{mmol} / \mathrm{l})\end{array}$ \\
\hline 1 & 17.7 & 4.4 & 6.8 & 41.8 & 2.8 & 62.7 & 4.7 & 1.54 \\
2 & 19.7 & 7.2 & 12.6 & 102.2 & 36.6 & 100.1 & 6.7 & 2.26 \\
3 & 23.5 & 4.9 & 8.9 & 280.8 & 10.3 & $\mathrm{ND}$ & 5.8 & 1.99 \\
$4^{\mathrm{a}}$ & 22.1 & 2 & 4.9 & $\mathrm{ND}$ & 2.5 & $\mathrm{ND}$ & 4.3 & 0.86 \\
5 & 18.4 & 6.1 & $\mathrm{ND}$ & $\mathrm{ND}$ & $\mathrm{ND}$ & $\mathrm{ND}$ & 6.1 & 2.03 \\
6 & 22.6 & 5.4 & 8.3 & 103.0 & 6.8 & 47.8 & 5.8 & 1.60 \\
7 & 21.6 & 5.7 & 8.5 & 82.8 & 11.6 & 51.0 & 5.5 & 1.60 \\
8 & 22.8 & 5.5 & 13.6 & 78.5 & 8.5 & $\mathrm{ND}$ & 6.3 & 2.28 \\
9 & 18 & 5.3 & 10.8 & 22.2 & 3.3 & 23.6 & 5.9 & 1.76 \\
10 & 23 & 4.9 & $\mathrm{ND}$ & $\mathrm{ND}$ & $\mathrm{ND}$ & $\mathrm{ND}$ & 5.1 & 1.33 \\
11 & 22.3 & 4.9 & 9.1 & 36.0 & 3.7 & 17.8 & 5.3 & 0.89 \\
12 & 24.6 & 5.1 & 8.3 & 44.9 & 5.7 & 42.8 & 4.7 \\
\hline
\end{tabular}

${ }^{\text {a }}$ Patient 4 was diagnosed as having insulinoma

Because of the unavailability of blood samples, some of the metabolic profiles were not determined (shown as ND)

$2 h-P G$ Plasma glucose at $2 \mathrm{~h}$ under the OGTT, $F P G$ fasting plasma glucose, $N D$ not determined

\section{Discussion}

GPR40 is abundantly expressed in murine pancreatic beta cells $[3,7]$ where it mediates the fatty acid-induced augmentation of GSIS in vitro [6]. Long-chain fatty acids act as ligands for human GPR40 in vitro [3, 7, 23]. Additionally, two studies suggest the possible involvement of GPR40 in the proliferation and cell function of breast cancer [27, 28]. Two laboratories reported the possible relationship between variation of the GPR 40 singlenucleotide polymorphisms and insulin secretion in humans $[22,23]$, where the results were inconsistent. The physiological role of GPR40 in humans remains obscure.

We here demonstrate for the first time that a large amount of GPR 40 mRNA is expressed in pancreatic islets in humans using expeditiously isolated islets from pancreatic tissue. TaqMan analysis revealed that levels of GPR 40

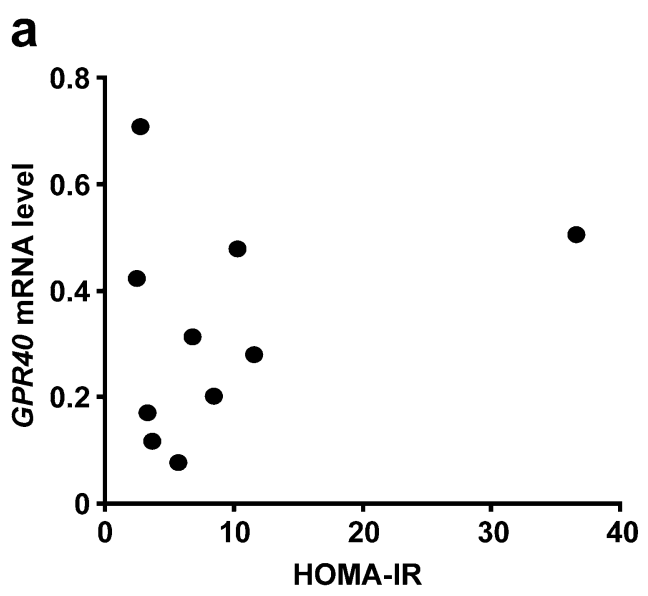

Fig. 3 Positive correlation between GPR 40 mRNA level in the pancreas and insulinogenic index. a Relationship between GPR40 mRNA level in the pancreas and the HOMA-IR $(n=10)$. GPR40 mRNA level and the HOMA-IR did not correlate significantly $(r=0.11, p=0.73)$. b Relationship between GPR40 mRNA level in
mRNA expression in pancreatic islets were 20 -fold higher than those in the pancreas in the same individuals. Notably, the mRNA level of the GPR40 gene in isolated islets was comparable to those of genes encoding GLP1R, ABCC8 (SUR1) and SSTRs, all of which are abundantly expressed in human pancreatic islets [13-16].

The present study demonstrates that a large amount of GPR40 mRNA is expressed solely in three cases of insulinoma among islet cell tumours. The finding suggests that the GPR40 mRNA detected in insulinoma is attributed to the type of islet cell tumour rather than the inclusion of endothelial, neuronal or other types of cells. Collectively, these data prompt us to speculate that GPR40 is expressed mainly in beta cells in the human pancreatic islet.

It is noteworthy that the mRNA levels of GPR40 and $A B C C 8$ (SUR1) were comparable in human pancreatic islets, because $A B C C 8$ (SUR1) is abundantly expressed in

b

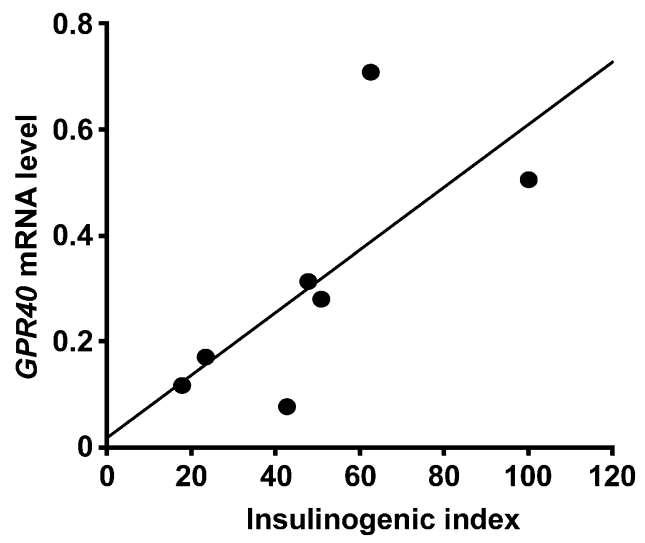

the pancreas and the insulinogenic index $(n=7)$. Correlation was marginally but significantly positive between GPR $40 \mathrm{mRNA}$ level and the insulinogenic index $(r=0.82, p=0.044)$. Spearman's rank correlation test was used to determine $p$ and $r$ values. The solid line is the regression line 
human pancreatic beta cells and the protein functions as a target of sulfonylurea agents [29]. These findings suggest that GPR 40 has also some functional property in terms of insulin secretion in humans. In the present study, the GPR40 mRNA level in the pancreas significantly correlated with the insulinogenic index rather than the HOMAIR, supporting the notion that GPR40 is involved in the regulation of insulin secretion in humans.

A recent study of GPR 40 knockout mice and beta-cellspecific GPR 40 transgenic mice provided evidence that GPR40 is involved in the pathophysiology of glucose intolerance and beta cell lipotoxicity [11]. In this context, it is important to note that patients enrolled in the present study were neither obese nor severely diabetic. Thus, clarification of the pathophysiological role of GPR40 in human diabetes must await further investigation in patients with a wider range of body weight, glucose intolerance or dyslipidaemia.

As pancreatic tissues are very vulnerable to postmortem autolysis, specimens obtained at operation have a great advantage for the precise analysis of the GPR40 mRNA level. Pancreatic biopsy is rarely conducted because of the risk of pancreatitis and is not justified in those without severe illness [30]. Thus, we analysed human pancreatic tissues collected during surgery. To our knowledge, specific antibody against human GPR40 has not been available, hence the lack of analyses of GPR 40 protein expression in the present study.

In summary, the present study demonstrates that GPR 40 mRNA is abundantly expressed in human pancreatic islets and insulinoma. The results provide evidence for GPR 40 expression in pancreatic beta cells and its involvement in insulin secretion in humans.

Acknowledgements We are grateful to M. Nagamoto for excellent technical assistance. This study was supported in part by a research grant from Special Coordination Funds for Promoting Science and Technology (JST, Japan); a Grant-in-Aid for Scientific Research (S2) (16109007), a Grant-in-Aid for Scientific Research (B2) (16390267), a Grant-in-Aid for Exploratory Research (16659243), and a Grant-inAid for Scientific Research on Priority Areas (15081101) from the Japanese Ministry of Education, Culture, Sports, Science and Technology; a Grant-in-Aid for Research (Japanese Ministry of Health, Labor and Welfare); a research award from the Japan Foundation for Applied Enzymology; the Yamaguchi Endocrine Research Association; the Cell Science Research Foundation; the Takeda Medical Research Foundation; the Smoking Research Foundation; and the Metabolic Syndrome Research Foundation. The authors are not aware of any duality of interest.

\section{References}

1. Nunez EA (1997) Biological complexity is under the 'strange attraction' of non-esterified fatty acids. Prostaglandins Leukot Essent Fat Acids 57:107-110

2. Corkey BE, Deeney JT, Yaney GC, Tornheim K, Prentki M (2000) The role of long-chain fatty acyl-CoA esters in beta-cell signal transduction. J Nutr 130:299S-304S

3. Briscoe CP, Tadayyon M, Andrews JL et al (2003) The orphan G protein-coupled receptor GPR40 is activated by medium and long chain fatty acids. J Biol Chem 278:11303-11311
4. McGarry JD, Dobbins RL (1999) Fatty acids, lipotoxicity and insulin secretion. Diabetologia 42:128-138

5. Unger RH (2003) Minireview: weapons of lean body mass destruction: the role of ectopic lipids in the metabolic syndrome. Endocrinology 144:5159-5165

6. Itoh Y, Kawamata Y, Harada M et al (2003) Free fatty acids regulate insulin secretion from pancreatic beta cells through GPR40. Nature 422:173-176

7. Kotarsky K, Nilsson NE, Flodgren E, Owman C, Olde B (2003) A human cell surface receptor activated by free fatty acids and thiazolidinedione drugs. Biochem Biophys Res Commun 301:406-410

8. Brown AJ, Goldsworthy SM, Barnes AA et al (2003) The orphan G protein-coupled receptors GPR41 and GPR43 are activated by propionate and other short chain carboxylic acids. J Biol Chem 278:11312-11319

9. Nilsson NE, Kotarsky K, Owman C, Olde B (2003) Identification of a free fatty acid receptor, FFA2R, expressed on leukocytes and activated by short-chain fatty acids. Biochem Biophys Res Commun 303:1047-1052

10. Hirasawa A, Tsumaya K, Awaji T et al (2005) Free fatty acids regulate gut incretin glucagon-like peptide-1 secretion through GPR120. Nat Med 11:90-94

11. Steneberg P, Rubins N, Bartoov-Shifman R, Walker MD, Edlund H (2005) The FFA receptor GPR40 links hyperinsulinemia, hepatic steatosis, and impaired glucose homeostasis in mouse. Cell Metabolism 1:245-258

12. Cameron, JL, Mehigan DG, Harrington DP, Zuidema GD (1980) Metabolic studies following intrahepatic autotransplantation of pancreatic islet grafts. Surgery 87:397-400

13. Giannaccini G, Lupi R, Trincavelli ML et al (1998) Characterization of sulfonylurea receptors in isolated human pancreatic islets. J Cell Biochem 71:182-188

14. Dillon JS, Tanizawa Y, Wheeler MB et al (1993) Cloning and functional expression of the human glucagon-like peptide-1 (GLP-1) receptor. Endocrinology 133:1907-1910

15. Thorens B, Porret A, Buhler L, Deng SP, Morel P, Widmann C (1993) Cloning and functional expression of the human islet GLP-1 receptor. Demonstration that exendin-4 is an agonist and exendin-(9-39) an antagonist of the receptor. Diabetes 42:1678-1682

16. Kumar U, Sasi R, Suresh S et al (1999) Subtype-selective expression of the five somatostatin receptors (hSSTR1-5) in human pancreatic islet cells: a quantitative double-label immunohistochemical analysis. Diabetes 48:77-85

17. Iwakura H, Hosoda K, Son C et al (2005) Analysis of rat insulin II promoter-ghrelin transgenic mice and rat glucagon promoter-ghrelin transgenic mice. J Biol Chem 280: $15247-15256$

18. Iwakura H, Hosoda K, Doi R et al (2002) Ghrelin expression in islet cell tumors: augmented expression of ghrelin in a case of glucagonoma with multiple endocrine neoplasm type I. J Clin Endocrinol Metab 87:4885-4888

19. Li Y, Kishimoto I, Saito Y et al (2004) Androgen contributes to gender-related cardiac hypertrophy and fibrosis in mice lacking the gene encoding guanylyl cyclase-A. Endocrinology 145:951-958

20. Saito S, Iida A, Sekine A et al (2002) Identification of 779 genetic variations in eight genes encoding members of the ATPbinding cassette, subfamily $\mathrm{C}$ (ABCC/MRP/CFTR). J Hum Genet 47:147-171

21. Haga H, Yamada R, Ohnishi Y, Nakamura Y, Tanaka T (2002) Gene-based SNP discovery as part of the Japanese Millennium Genome Project: identification of 190,562 genetic variations in the human genome. Single-nucleotide polymorphism. J Hum Genet 47:605-610

22. Ogawa T, Hirose H, Miyashita K, Saito I, Saruta T (2005) GPR40 gene Arg211His polymorphism may contribute to the variation of insulin secretory capacity in Japanese men. Metabolism 54:296-299 
23. Hamid YH, Vissing H, Holst B et al (2005) Studies of relationships between variation of the human $G$ protein-coupled receptor 40 gene and type 2 diabetes and insulin release. Diabet Med 22:74-80

24. Ferrannini E, Gastaldelli A, Miyazaki Y, Matsuda M, Mari A, DeFronzo RA (2005) Beta-cell function in subjects spanning the range from normal glucose tolerance to overt diabetes: a new analysis. J Clin Endocrinol Metab 90:493-500

25. Matthews DR, Hosker JP, Rudenski AS, Naylor BA, Treacher DF, Turner RC (1985) Homeostasis model assessment: insulin resistance and beta-cell function from fasting plasma glucose and insulin concentrations in man. Diabetologia 28:412-419

26. Takahashi-Yasuno A, Masuzaki H, Miyawaki T et al (2004) Association of $\mathrm{Ob}-\mathrm{R}$ gene polymorphism and insulin resistance in Japanese men. Metabolism 53:650-654
27. Yonezawa T, Katoh K, Obara Y (2004) Existence of GPR40 functioning in a human breast cancer cell line, MCF-7. Biochem Biophys Res Commun 314:805-809

28. Hardy S, St-Onge GG, Joly E, Langelier Y, Prentki M (2005) Oleate promotes the proliferation of breast cancer cells via the $\mathrm{G}$ protein-coupled receptor GPR40. J Biol Chem 280: 13285-13291

29. Gribble FM, Reimann F (2003) Sulphonylurea action revisited: the post-cloning era. Diabetologia 46:875-891

30. Imagawa A, Hanafusa T, Uchigata $Y$ et al (2005) Different contribution of class II HLA in fulminant and typical autoimmune type 1 diabetes mellitus. Diabetologia 48:294-300 